\title{
Curing the Vampire Disease with Transfusion: The Narrative Structure of Bram Stoker's Dracula
}

\author{
Anthony Salazar ${ }^{1}$ \\ ${ }^{1}$ Department of English, Ball State University, Indiana, United States \\ Correspondence: Anthony Salazar, Department of English, Ball State University, Indiana, United States. E-mail: \\ asalazar@bsu.edu
}

Received: May 19, 2017 Accepted: June 16, 2017 Online Published: August 9, 2017

doi:10.5539/ells.v7n3p1 URL: http://doi.org/10.5539/ells.v7n3p1

\begin{abstract}
Blood transfusion in Bram Stoker's Dracula serves as a vital component to life for characters who have been bitten by vampires. But blood transfusion can mean much more when comparing it to the narrative's structure. While characters contribute to the narrative, parallels between blood transfusion and narrative assembly emerge, which thus grants characters within the novel immortality as their writing lives on while they slowly die from the vampire disease. Although transitioning into a vampire can also grant these characters immortality, vampires and other supernatural creatures during the Victorian Era were frowned upon by nineteenth century values and religious beliefs. Therefore, seeking immortality through narration allows these characters to abide to Victorian values while also living eternally.
\end{abstract}

Keywords: blood transfusion, bram stoker, dracula, narrative theory, vampire, victorian studies, narrative structure

\section{Introduction}

The growth of vampire fiction during the nineteenth century attracted a full spectrum of audiences; particularly the everyday reader. And though vampires have been interpreted in a multitude of ways, most writers during the nineteenth century depicted vampires as evil creatures who feed from the living. But, unlike zombies or other animalistic monsters who hunt for their food, the vampire's diet consists of blood without the victim's flesh, which can perhaps explain the expansion of the vampire genre as Victorians strongly believed that blood, according to their religious beliefs, was the key to life - it could both kill and save based on the amount of blood in one's body (Tiziani, 2009, p. 133).

As one of the many texts of vampire fiction during the nineteenth century, Bram Stoker's Dracula encompasses the importance of blood. After attacking Dr. Seward, Renfield utters, "The blood is the life! The blood is the life" (Stoker, 1897/2016, p. 158). But what exactly does Renfield mean when he admits this to the attendants and Dr. Seward? Although Renfield is not a vampire, he nonetheless acknowledges - in opposition to the other characters' initial ignorance - that "blood is the life." As iterated by Renfield, the extraction of blood provides oneself additional strength that cannot be obtained elsewhere. Consuming living blood, however, violates the Old Testament for, according to Deuteronomy 12.23, "Only be sure that thou eat not the blood: for the blood is the life; and though mayest not eat the life with the flesh." Because the Bible cautions followers against consuming blood, perhaps the growth of the vampire genre poses as a warning against medical advancements, especially blood transfusion. However, the characters within Dracula have faith that their experiments bypass Biblical warnings due to their methods being deemed acceptable by Western World culture. In other words, Victorians' obsession with controlling life parallels with the vampire's craving for living blood. Thus, their desires and appetites for life fuels the vampire genre.

By connecting energy to transfusion, my objective within this essay is to discuss the appetites-both desires and cravings - between the living and the living dead in Bram Stoker's Dracula. This, I believe, has been quite neglected by scholars who study Stoker's work. Although they seem to reference the use of blood to gender and sexuality (Pelis, 1999; Stephanou, 2013) and disease (Stephanou, 2013; Willis, 2007), a lack of scholarship emerges as they neglect to analyze blood in its simplest and most literal use: to transfer energy from one host to another. That is to say, scholars neglect the connection of blood to energy, and to ignore this connection also ignores the correlation of transfusion and narrative assembly. Transfusion further drives these characters toward 
eternal life through their writing. Though transitioning into a vampire provides an easier path towards immortality, the characters within Dracula choose immortality through writing as a way of abiding to Western World values that frown upon immortality through the vampire disease.

\section{Energy Between the Living and the Living Dead}

While we now perceive blood transfusion as a minor procedure, nineteenth century Victorians were quite cautious of such a procedure due to fatal results. According to Paul Giangrande, the use of blood transfusion "only became a part of routine clinical practice relatively recently. Blood-letting (venesection) was widely practiced for a variety of medical conditions from the time of Hippocrates through the nineteenth century in Europe and yet transfusion only became a commonplace therapeutic intervention less than 100 years ago" (2000, p. 758). Put in another way, releasing blood served as a widespread practice throughout history, yet transferring blood from one body to another is a relatively new procedure. In fact, within the seventeenth century, many scientists and medical doctors initially experimented blood transfusion between cross species, including humans. Yet these transfusions always failed due to incompatible blood mixing. Then, in the 1828 edition of The Lancet, medical scientist James Blundell revealed that "if blood of an animal of the same species was transfused, in almost every case speedy and complete recovery ensued; if the transfused blood was taken from an animal of a different species, a transient reaction only took place, and death followed before the sixth day" (1828, pp. 325-326). While recalling a previous experiment, Blundell reported that "The blood of sheep injected into the veins of ducks produced very violent convulsions and death shortly after the experiment" (1828, p. 326). Perhaps, to relate Blundell's findings to the novel, the transfusion between Count Dracula and his victims are more than a transfer of the vampire disease. They are, instead, the result of failed transfusion due to the inability to mix blood from two different species. This, according to Van Helsing, can be viewed as a transfusion of poison/disease from vampire to human, or "the Vampire's Baptism of blood" (Stoker, 1897/2016, p. 321).

But to consider vampires as an entirely separate species entails many considerations. On the one hand, vampires originate as humans and can still be perceived as human equivalents due to shared anatomical features and intelligence. On the other hand, vampires' capabilities in Dracula extends beyond humans due to their added strength and ability to morph into bats. In a way, vampires can be perceived as evolved forms of humans with slightly uncontrollable animalistic characteristics. As Charles Darwin puts it, "man is descended from some less highly organized form" (1871/2004, p. 676). To add vampires to the equation infers that being human is the "less highly organized form."

Humans further differ from vampires in terms of controlling appetites. When Johnathan cuts his face in front of the Count while shaving in the beginning of the novel, the Count transforms from a weak, old man to a savage animal who can barely resist Johnathan's blood. Johnathan writes, "When the Count saw my face, his eyes blazed with a sort of demoniac fury, and he suddenly made a grab at my throat. I drew away, and his hand touched the string of beads which held the crucifix. It made an instant change in him, for the fury passed so quickly that I could hardly believe that it was ever there" (Stoker, 1897/2016, p. 52). The presence of blood, as exemplified in this scene, infers that controlling appetites for vampires is quite challenging. This further suggests that the vampire disease (and animalistic traits) alternates between a dormant and active state that depends on the situation and environment. However, at this stage in the novel, the Count still requires Johnathan's assistance and therefore must resist his urge for blood. He even warns Johnathan later within the chapter to remain within his quarters, saying that the castle "is old, and has many memories, and there are bad dreams for those who sleep unwisely. Be warned! Should sleep now or ever overcome you, or be like to do, then haste to your own chamber or to these rooms for your rest will then be safe" (Stoker, 1897/2016, p. 59). But as Johnathan ignores the Count's demands and explores the castle, he encounters three female vampires, describing one of them as "thrilling and repulsive, and as she arched her neck she actually licked her lips like an animal" (Stoker, 1897/2016, p. 64). Similar to the Count, these female vampires also appear to be under the disease's influence, unable to control their animalistic appetites for living blood. The altered personalities of vampires while surrounded by the living therefore infers that, although vampires and humans share the same anatomical structure, vampires are beyond the human figure and can then be viewed as a separate species.

\subsection{Transfusing Blood for Strength}

What strikes me as particularly interesting about the transfusion between humans in the novel is Van Helsing's reoccurring success when operating on Lucy and Mina. According to Aspasia Stephanou, blood transfusion during the second half of the nineteenth century was "generally unsuccessful because of the lack of sterilization procedures, knowledge of blood groups, and blood clotting in needles and tubes" (2013, p. 55). Because of this, it seems nonsensical for Van Helsing to successfully transfuse without any error. Perhaps, because the novel was 
written during a time of blind experiments, the success of every transfusion was a result of gendered misconceptions that occurred during the late nineteenth century. As iterated by Sos Eltis in "Corruption of the Blood and Degeneration of the Race," the use of blood transfusion was almost always given to weak women by strong men (2016, p. 573), which correlates to Blundell's "Observations on Transfusion of Blood." Though Blundell refrains from outwardly correlating gender to transfusion, the image used to visually describe the Gravitator (Blundell's machine that he used for transfusion) shows a weak, frail woman in bed while a strong man boldly stands next to her, donating his blood to save her life. It is thus quite possible that transfusions given in Dracula succeed every time solely because they involve transfusion between weak women and strong men.

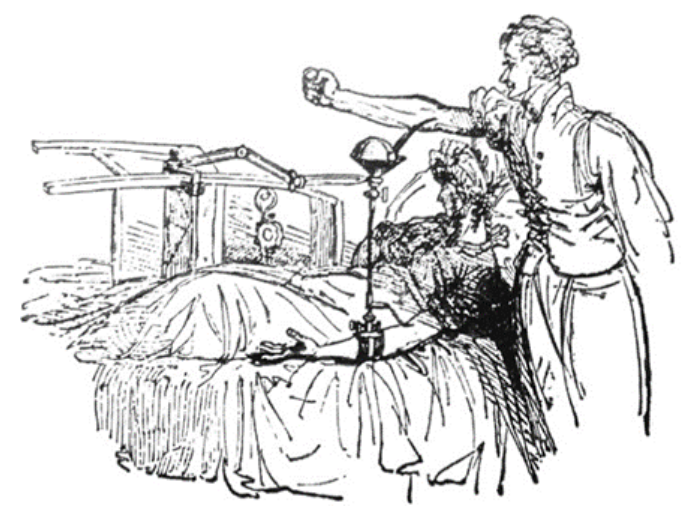

Figure 1. Blood transfusion with the Gravitator, shown in The Lancet (1828)

When Lucy's health deteriorates, requiring transfusion, Van Helsing and Dr. Seward discuss who should donate blood and realize that Arthur, who just arrived, should be the donor. As Van Helsing reasons to Arthur, "My friend John and I have consulted; and we are about to perform what we call transfusion of blood - to transfer from full veins of one to the empty veins which pine for him. John was to give his blood, as he is the more young and strong than me... but, now you are here, you are more good than us, old or young, who toil much in the world of thought. Our nerves are not so calm and our blood not so bright than yours" (Stoker, 1897/2016, p. 140) Not only does the quality of blood during the Victorian Era heavily prize youth and strength, but also nerve. Van Helsing later mentions during another blood transfusion that "a brave man's blood is the best thing on this earth when a woman is in trouble" (Stoker, 1897/2016, p. 165). By correlating transfusion to gender stereotypes in the nineteenth century, we can perhaps understand why transfusion was always successful: the mindset of Victorian science and medicine thrived on the belief that transfusion was powered by gender roles. Van Helsing later pleads, "She will die of sheer want of blood to keep the heart's action as it should be" (Stoker, 1897/2016, p. 139). By Van Helsing claiming that Lucy wants blood, as opposed to Lucy claiming an urgency for blood, he seems to inflict gendered views of transfusion without her opinion. This excerpt further implies that blood as energy can only work when applied to those who lack blood. For vampires, however, the urgency for blood never ends.

As Count Dracula drains Lucy's blood, Van Helsing transfuses more to supply her with a sufficient amount. Thus, when Renfield pleads for blood, he does so while solely correlating his appetite to the vampire's constant need for blood as opposed to humans' occasional need due to the lack of blood. However, this fails for Renfield since he's unaffected by the vampire disease. After Renfield consumes living birds for their blood, he becomes sick. Dr. Seward writes, "The attendant has just been to me to say that Renfield has been very sick and has disgorged a whole lot of feathers. "My belief is, doctor," he said, "that he has eaten his birds, and that he just took and ate them raw"' (Stoker, 1897/2016, p. 94). Therefore, it seems as though to consume blood, one must be short of it to produce a successful transfusion. Renfield, in this case, is not only unaffected by the disease- thus not requiring blood - but also consumes his prey incorrectly as he focuses on the blood and flesh, instead of just the blood.

Transfusion between an infected human and a noninfected human can also be problematic, resulting with the inability to entirely cure the vampire disease. Although transfusion initially helps rejuvenate Lucy and Mina, they seem to worsen as the Count returns for more blood and transfuses his blood into the women. When the troupe check on Mina, they find her in her bedroom, drinking the Count's blood. Dr. Seward recollects, "With [the Count's] left hand he held both Mrs. Harker's hands, keeping them away with her arms at full tension; his right hand gripped her by the back of the neck, forcing her face down on his bosom. Her white nightdress was 
smeared with blood, and a thin stream trickled down the man's bare breast which was shown by his torn-open dress" (Stoker, 1897/2016, p. 285). By feeding diseased blood to Mina, the Count transfuses the vampire disease into her, thus diluting disease into her healthy body. Examining blood as a host capable of becoming diseased, however, reveals other symbolic explanations within the novel, such as the novel itself.

\section{The Bleeding Narrative}

When Renfield attempts to prove his sanity, he admits to the troupe that he attacked Dr. Seward for his energy and youth. He claims, "I tried to kill him for the purpose of strengthening my vital powers by the assimilation with my own body of his life through the medium of his blood-relying, of course, upon the Scriptural phrase, "For the blood is the life"" (Stoker, 1897/2016, p. 241). And thus, due to the influence of the Old Testament, Renfield unsuccessfully attempts to kill the doctor in pursuit of energy and strength. But, as I have previously mentioned, the use of blood as energy can also be expressed through blood transfusion. When Lucy's health dwindles due to the vampire disease, blood provided by strong, living men serves as a temporary cure to revitalize her fatigue. But because the diseased blood from within her body dilutes their blood, she requires a steady supply of uninfected blood as the vampire disease grows stronger. The use of transfusion therefore serves as a revitalization mechanism that keeps Lucy alive and her craving for blood under control. As a result, blood transfusion unites the troupe through their need to combine forces to prevent Lucy's death. Arthur utters, "What can I do? Tell me, and I shall do it. My life is hers, and I would give the last drop of blood in my body for her" (Stoker, 1897/2016, p. 139). The sharing of blood that these characters engage in also parallels with the narrative structure.

In "The Narrative Method of Dracula," David Seed argues that "Only of recent years have critics begun to examine [the novel's] methods, and even now all too little attention is paid to its formal complexities" (1985, p. 61). As a result of the lack of narrative discourse, Seed's essay examines the structure of the novel and the purpose of Dracula's anticlimactic death. Although Seed argues for an interesting telling of the novel's structure, he does so while ignoring the multiple narratives and Gothic elements that surround the characters' decisions and purposes for writing. This, I believe, leaves a gap within the connection between blood, transfusion, and narrative assembly.

In the beginning of the novel, we follow Johnathan as he journeys to Transylvania while writing everything he encounters in his journal. Through Johnathan's writing, we find out that his original intentions for writing solely rested on remembering his traveling experiences. He claims, "I shall enter here some of my notes, as they may refresh my memory when I talk over my travels with Nina" (Stoker, 1897/2016, p. 29). The concept of writing for remembrance also serves as a driving force for others within the novel, such as Dr. Seward and his observation journals. We even experience writing for remembrance through businesses that the troupe interrogates while discovering the whereabouts of Count Dracula. While Dr. Seward seeks the locations of the Count's coffins, he encounters one business in particular who reflect on their writing to help the doctor. He writes that the business "looked up the transaction in their day-book and letter-book, and at once telephoned to their King's Cross office for more details. By good fortune, the men who did the teaming were waiting for work, and the official at once sent them over, sending also by one of them the way-bill and all the papers connected with the delivery of the boxes at Carfax" (Stoker, 1897/2016, p. 236). Though the business's intentions differ from the troupe's purpose of killing Dracula — and therefore the vampire disease - they are still writing in their books for remembrance, thus unintentionally contributing to the overall narrative. Writing further provides the troupe with the opportunity to reach outside readers. As Lucy writes in her diary, "I must imitate Mina, and keep writing things down" (Stoker, 1897/2016, p. 128). Though she is not required to write for others, she feels compelled to continue, believing that an unknown reader will one day benefit from her writing.

Feeling obligated to contribute to the narrative also persists among the other characters. From Dr. Seward, who writes "Let all be put down exactly" (Stoker, 1897/2016, p. 150) to Van Helsing, who says "Read all, I pray you, with the open mind; and if you can add in any way to the story here be told do so, for it is all-important" (Stoker, 1897/2016, p. 228), all characters within the troupe feel obligated to write down their experiences. Though it starts with Johnathan writing to please Mina, everyone eventually succumbs to this arduous task. But writing also provides a greater purpose: to relay their story to future, unknown readers. As Dr. Seward expresses, "this very script may be evidence to come between some of us and a rope" (Stoker, 1897/2016, p. 332). The shared narrative, however, correlates to Stephanou's concept of community growth through blood transfusion. Because blood transfusion prevents death by the help of donors, it becomes quite clear to see the correlation of Dracula's structure. All of the characters are bound together to donate their time and effort to keep the narrative alive, for it is the narrative that ultimately suffers from the vampire disease. 


\subsection{Transfusing Gender Roles}

As Lucy slowly dies, she writes, "I feel I am dying of weakness, and have barely strength to write, but it must be done if I die in the doing" (Stoker, 1897/2016, p. 159). Even though she is moments away from death, she still feels obligated to relay all of the information that she possesses, for she believes that doing so will allow her story to be heard, which, by extension, means that she can continue to live. Or perhaps her written personae as the living can continue to effect others' opinions of her, for when she transforms into the living dead, her personality alters completely. Therefore, because her writing exists due to her determination, she becomes paradoxically living and living dead, presented within two different forms prior to her execution as the living dead by the troupe.

The concept of split identities between writing and one's self is also shown when Mina reflects on Dr. Seward's diary entries on his phonograph. Mina observes that "That is a wonderful machine, but it is cruelly true. It told me, in its very tones, the anguish of your heart. It was like a soul crying out to almighty God. No one must hear them spoken ever again! ...none other need now hear your heart beat, as I did" (Stoker, 1897/2016, p. 231). Though the phonograph entries were not in writing until Mina transcribed them, we can still observe how technology creates multiple identities that allows us to exist in two places at once, or exist beyond our death-it's as if a writer's existence and heartbeat emerge while readers engage in the writing.

But Dracula isn't the only text that toys with this concept. Living eternally through writing, in fact, also exists in other works of literature, not just in Victorian literature. Shakespeare's eighteenth sonnet, for example, mentions immortality as a benefit for engaging in lustrous acts with writers. He writes, "thy eternal summer should not fade / Nor lose possession of that fair thou ow'st / Nor shall death brag though wander'st in his shade / When in eternal lines to time thou grow'st, / So long as men can breathe or eyes can see, / So long lives this, and this gives life to thee" (Shakespeare, 1609/2008). Similar to Shakespeare's sonnet, it seems as though Lucy wishes to live immortally through her writing. Thus, she eagerly writes to transfuse herself into the novel.

Unlike Lucy, Dr. Seward has an opposing feeling towards writing. Upon hearing what they must do to Lucy as a way of destroying the vampire disease that transforms her into the living dead, Dr. Seward utters, "So I can finish this diary; and God only knows if I shall ever begin another. If I do, or if I ever open this again, it will be to deal with different people and different themes; for here at the end, where the romance of my life is told, ere I go back to take up the thread of my life-work, I say sadly and without hope" (Stoker, 1897/2016, pp. 189-190). His experiences of writing, therefore, contrasts from Lucy's experiences due to the pain he feels when reliving the past, while Lucy finds great determination in doing so. What's particularly interesting about the opposing feelings between Lucy and Dr. Seward is that if we examine the novel as a blood transfusion, then it only seems fitting for Lucy to feel dismal while Dr. Seward should feel empowered to continue the narrative. Because Lucy is a weak, fragile woman, she would not be able to feed the narrative, or, metaphorically speaking, transfuse her energy into the text in accordance to the medical theories of the Victorian Era. But because she does it ever so willingly and with delight, her masculine personality emerges, which also parallels with Mina's view of writing to strengthen the narrative. The opposite occurs with Dr. Seward and Johnathan. Because they despise writing, they seem to resemble weak, fragile women who are unfit to transfuse their energy. Although they end up transfusing their energy to keep the narrative alive, they do so in a way that puts shame to the masculine image that they must proclaim in Victorian society.

As the novel progresses, the characters who fear contributing to the narrative mask their fear by proclaiming the masculine role they were destined to fulfill. Although Johnathan promises to never write in his journal after his experience in Transylvania, he strengthens up, writing, "I thought never to write in this diary again, but the time has come" (Stoker, 1897/2016, p. 199). Even Dr. Seward accepts his title as a masculine character by agreeing to transfuse his energy into the narrative. He writes, "Truly there is no such thing as finality. Not a week since I said "Finis," and yet here I am starting fresh again, or rather going on with the same record" (Stoker, 1897/2016, p. 201). While the narrative shifts towards a foreseeable conclusion, the characters transition their purpose from wanting others to read their story to themselves needing to read their story for both verification and proof. Johnathan writes, "I must keep writing at every chance, for I dare not stop to think. All, big and little, must go down; perhaps at the end the little things may teach us most" (Stoker, 1897/2016, p. 291). Thus, to summarize, the characters' purpose of writing is to 1) entertain and provide remembrance, 2) inform others, and 3) provide a source of community growth as they transfuse their energy into one. But to keep the narrative alive implies that the narrative is, in a way, diseased.

\subsection{Transfusing to Purify the Vampire Disease}

As I have previously mentioned, the purpose of blood transfusion is to restore energy into the weak and dying. 
The story itself, however, serves as a disease according to the Old Testament. Because one should not extract blood from the living, the troupe continues to feed the narrative as a way of reviving and purifying the sinful actions depicted in the novel. Though as Count Dracula spreads disease by drinking his victims' blood, the troupe feels obligated to prevent him from infecting additional, uninfected humans. They therefore feel compelled to kill Count Dracula and complete the narrative as a way of purifying the experiences that have occurred. When Mina speaks to the troupe prior to attacking the Count, she remarks, "That poor soul who was wrought all this misery is the saddest case of all. Just think what will be his joy when he too is destroyed in his worser part that his better part may have spiritual immortality. You must be pitiful to him too, though it may not hold your hands from his destruction" (Stoker, 1897/2016, pp. 308-309). In other words, Mina sees through the Count's demure and believes that his soul cannot break free from the disease. Thus, they must kill the Count with pity for he himself is only a product of the infectious disease.

But perhaps there is an alternate motive that drives the troupe's continuation of the narrative. Because the medical field during the nineteenth century was flourishing, blood transfusion was quite new in terms of success. Therefore, feeding the narrative could perhaps be the troupe's way of repenting for the multiple blood transfusions that they performed on Lucy. To feed the narrative results only in its purification, as expressed through the Count's death. Therefore, the compelled obligation to complete the narrative lies within the troupe's determination to relinquish the vampire genre and as a way of repenting the bible's warning to refrain from consuming living blood.

\section{Conclusion}

In the beginning of this essay, I proposed that blood as a source of energy should be analyzed in Stoker's Dracula, particularly in relation to disease and medical science during the nineteenth century. Ultimately, this analysis led from the parallels between disease and blood transfusion to the overall structure and creation of the narrative. I would therefore like to spend these last moments finalizing my thoughts on appetites from both the living and the living dead.

There are many occurrences within the novel that depict appetites as uncontrollable cravings while other occurrences infer that appetites are desires for energy, primarily controlled by blood. When Lucy persists on finishing her diary, we can observe her masculine desires as an appetite for eternal life through her writing. Thus, through her calm determination, she seems to have control of her desires. This then infers that appetites are more of a selfish want due to her ability to control and resist the temptation. In Lucy's case, the selfish want would be for her words to live on while she transforms into a vampire. Although writing does not impact her immediate living state, she persistently continues even though Van Helsing advises her against exerting unneeded energy. As an opposition to Lucy's appetite, we can observe Count Dracula's craving for Johnathan's blood as an uncontrollable appetite that can only be subdued with a crucifix. This then infers that uncontrollable appetites are perceived as unselfish due to the Count's inability to withhold. While Lucy has a desire for immortality within a living state, the Count has a craving for Johnathan's blood. Perhaps more could be said about these characteristics, though. From analyzing these two binaries, it seems as though controllable appetites are reserved for the living, whereas uncontrollable appetites are reserved for the living dead during their active, animalistic outbursts.

The notion of human and animal characteristics is also shown through blood transfusion. Though it is quite possible that both living and living dead are sinners in accordance to the bible, they could, in terms of Victorian standards, represent the proper and barbaric ways of transfusing energy. While vampires bite to extract blood from their victims, scientists and medical doctors use tools, such as Brundell's Gravitator, to transfer blood. Though one is forced and the other is voluntary, I still find it important to note the social acceptance of one method verse the other. As Van Helsing claims, "We have on our side power of combination - a power denied to the vampire kind; we have resources of science; we are free to act and think; and the hours of the day and the night are ours equally. In fact, so far as our powers extend, they are unfettered, and we are free to use them. We have self-devotion in a cause, and an end to achieve which is not a selfish one. These things are much" (Stoker, 1897/2016, p. 245). Thus, appetites - both desires and cravings - are then defined by social acceptance and our ability, or inability, to withhold our appetites. In terms of proper ways to transfer energy, to live eternally through narration grants the characters within Dracula the social acceptance of immortality, while the vampire disease and genre remain a social and undesirable appetite in accordance to Victorian values.

\section{Acknowledgement}

I would like to awknowledge and thank Dr. Joyce Huff for all her advice and encouragement during the drafting stages of this article. 


\section{References}

Blundell, J. (1828). Observations on transfusion of blood. The Lancet, 2(302), 321-326.

Darwin, C. (2004). The decent of man. London: Penguin Group.

Elis, S. (2016). Corruption of the blood and degeneration of the race: Dracula and policing the borders of gender. In J. P. Riquelme (Ed.), Dracula (pp. 565-580). Massachusetts, United States: Bedford St. Martin.

Giangrande, P. (2000). The history of blood transfusion. British Journal of Hematology, 110(4), 758-767. http://dx.doi.org/10.1046/j.1365-2141.2000.02139.x

Pelis, K. (1999). Transfusion, with teeth. Manifesting Medicine —Bodies and Machines, 1-26.

Seed, D. (1985). The narrative method of dracula. Nineteenth-Century Fiction, 40(1), 61-75. http://dx.doi.org/10.2307/3044836

Shakespeare, W. (2008). Sonnet 18. In S. Greenblatt (Ed.), The Norton Shakespeare (1674). New York: W. W. Norton \& Company.

Stephanou, A. (2013). A "ghastly operation": Transfusing blood, science, and the supernatural in vampire texts. Gothic Studies, 15(2), 53-65. https://doi.org/10.7227/GS.15.2.4

Stoker, B. (2016). Dracula. In J. P. Riquelme (Ed.), Dracula (pp. 25-371). Massachusetts, United States: Bedford St. Martin.

Tiziani, M. (2009). Vampires and vampirism: Pathological roots of a myth. Antrocom, 5(2), 133-137.

Willis, M. (2007). “The Invisible Giant," Dracula, and Disease. Studies in the Novel, 39(3), 301-325.

\section{Copyrights}

Copyright for this article is retained by the author, with first publication rights granted to the journal.

This is an open-access article distributed under the terms and conditions of the Creative Commons Attribution license (http://creativecommons.org/licenses/by/4.0/). 